\title{
Pingos and old sub-permafrost water at Svalbard
}

\author{
YISHAI WEINSTEIN ${ }^{1}$, DOTAN ROTEM ${ }^{1}$, ANDREW \\ HODSON $^{2}$ AND HANNE HVILDTFELDT CHRISTIANSEN ${ }^{2}$ \\ ${ }^{1}$ Bar-Ilan University \\ ${ }^{2}$ The University Centre in Svalbard (UNIS) \\ Presenting Author: weinsty@biu.ac.il
}

Permafrost covers about $25 \%$ of the northern hemisphere land. Sub-permafrost hydrology is complicated, in particular in continuous permafrost terrains. Pingos are positive structures, the result of sub-permafrost groundwater discharge. Basically, pingo is a small hill, which builds up from below by the accumulation of ice due to near-surface freezing of upwelled groundwater. There are closed-system pingos and open-system ones. The closed-system pingos are produced by local permafrost thawing (thermo-karst), usually associated with continuous permafrost landscape, while the open-system ones are fed by meteoric water of recent recharge, and are usually associated with discontinuous permafrost.

Pingos at Svalbard were traditionally considered of the opensystem style, owing to the scarcity of thermo-karst features and due to their location in valleys surrounded by high topography, believed to be the source for the sub-permafrost water. The continuous nature of the permafrost and the lack of wet-based glaciers led Hornum et al.[1] to challenge this view. They alternatively suggested that the pingos are of the closed-system style, and that the pingo-related groundwater is local, probably old sub-permafrost water, which is being pressed by the permafrost active downward aggradation.

We studied radium isotopes and ${ }^{3} \mathrm{H}$ in artesian water discharging at five pingos at the valley of Adventdalen, Svalbard. ${ }^{3} \mathrm{H}$ data suggest that all water include old (older than 60 years) component. While in one pingo, the old component is $\sim 50 \%$ of discharge, in two other pingos it is $\geq 90 \%$, and in two pingos there is no young water at all. Close to equilibrium ratios of ${ }^{226} \mathrm{Ra} /{ }^{223} \mathrm{Ra}$ in most samples suggest that the old water is at least several hundred years old, which is supported by high ratios of ${ }^{226} \mathrm{Ra} / \mathrm{Cl}$ and ${ }^{226} \mathrm{Ra} / \mathrm{Ca}$. This further supports the paradigm of closed-system pingos, although the exact age of discharging water should be further studied.

[1] Hornum, Hodson, Jessen, Bense \& Senger (2020), The Cryosphere 14, 4627-4651 